\title{
THE IMPACT ON DOMESTIC PRODUCTIVITY OF INWARD INVESTMENT IN THE UK.
}

The Manchester School, Vol. 69(1) pp103-119

\author{
Nigel Driffield, \\ Cardiff Business School, \\ Colum Drive, \\ Cardiff, \\ CF10 3EU. \\ UK. \\ email: driffield@cardiff.ac.uk
}

\section{forthcoming in The Manchester School}

\begin{abstract}
This paper examines one of the basic tenets of UK industrial policy, that attracting inward investment into the UK stimulates domestic productivity growth. A model of productivity growth is developed for the indigenous sector of UK manufacturing, linking domestic productivity growth to theoretical explanations of inward investment. The paper demonstrates that inward investment does stimulate productivity growth in the domestic sector of around $0.75 \%$ per annum. However, this cannot be attributed to investment or output spillovers, but as a result of the productivity advantage exhibited by the foreign firms.
\end{abstract}

\footnotetext{
J.E.L. classification: O31, F23

keywords : productivity growth, inward investment.

word count 6313 inclusive
}

\footnotetext{
* I would like to express thanks to Mick Silver and two anonymous referees for helpful comments on a previous draft. Any remaining errors are of course mine.
} 


\section{Introduction.}

It is a long held view that one of the major benefits to a host country of foreign direct investment (FDI), is the superior foreign technology that accompanies the investment. Indeed, this belief is one of the central tenets of the inward investment policy pursued by the UK government since the mid 1980’s. ${ }^{1}$ Multinational enterprises (MNEs) are assumed to be more technologically advanced than their domestic counterparts, and consequently some of this superior technology may be assimilated by host country firms. As is shown in section 2, this hypothesis is founded on the traditional theoretical analysis of multinational enterprises, based on ownership advantages.

The following section discusses in detail the rationale for expecting host country productivity growth to follow inward investment. Section three outlines the model of productivity growth, based on factor inputs, spillovers and technological advance through R\&D. Sections four and five deal with the econometric issues; measuring inward investment, and endogeneity of R\&D within a model of productivity externalities. The remaining sections are concerned with the data employed, the results and conclusions.

\section{Inward investment and domestic productivity growth}

While the thrust of this paper is to test the extent to which inward investment generates a gain in domestic productivity, it will also show that an important determinant of this is the motivation for the initial investment. This section briefly discusses the theoretical and empirical explanations of inward investment, on which the hypotheses concerning the possible relationship between inward investment and productivity growth can be based.

Most traditional theories of FDI activity, are based on Dunning's (1979) eclectic paradigm, and particularly on the concept of ownership advantages. Such firm specific advantages are often characterised as technology based, relating to economies of scale, capital intensity and 
R\&D. Indeed, Blomstrom and Kokko (1996) provide several reasons why such technology is expected to transfer from MNEs to domestic firms. This can occur directly, through the licensing of a particular technology, through supplier networks or subcontracting arrangements, or indirectly as knowledge becomes public, and spillovers are assimilated by the domestic sector. Barrell and Pain (1997) estimate that around 30\% of the productivity growth in UK manufacturing between 1985 and 1995 could be associated to the impact of inward investment. The 'ripple through' effects of changes in production and working practices triggered by the presence of new inward investors have been particularly important. The above suggests that there could be productivity gains at the industry level connected with foreign investment in that industry. Secondly, there is the possibility that this technology 'spills over' in a less formal manner to domestic firms. The literature on technology externalities is now well developed, see for example Griliches (1992) for an excellent survey of this literature.

An important concept in the study of spillovers, is the extent to which agglomeration economies occur. Such economies arise from the geographic proximity of similar, technologically advanced enterprises. The presence of MNEs, as leaders in both technological and capital accumulation, will serve to stimulate further the possibility for agglomeration in such locations (Cantwell, 1989). This will serve to increase the potential for technology transfer, and therefore improvements in the technological capabilities of domestic firms.

The third possibility for increased domestic productivity concerns the types of advantages that MNEs may possess. The non-technological advantages, such as managerial abilities, the exploitation of scale economies, or superior co-ordination of resources, if adopted by host country industry, may improve performance. A further possibility, related to the transfer of ownership advantages, is the 'demonstration effect', Caves (1996), including 
phenomena such as local firms learning better management techniques, or developing coordination economies as a result of the foreign investment. The so called 'Japanisation of UK industry' is a case in point. Markusen (1995) extends such analysis, to show that 'knowledge capital' is likely to be a more important source of ownership advantages, than is physical capital. Knowledge capital is clearly more easily transferable internationally than is physical capital, and as such, Markusen (1995), based on the work of Brainard (1997) and Horstmann and Markusen (1992) shows that multinational activity arises through R\&D and transaction costs, and where firm level scale economies are greater than plant level ones. Under such circumstances, one would expect MNEs to have certain productivity advantages over domestic firms, and indeed this is borne out by UK data, Davies \& Lyons (1991).

In addition to ownership advantages, explanations of FDI also place emphasis on location advantages, FDI being attracted to a particular location due to the endowments of particular factors of production. Indeed, Maskus and Webster (1995) for example, demonstrate that this is an important phenomenon. If FDI is attracted to the UK for reasons of low labour costs, or a successful domestic sector for example, then it is less clear why technology spillovers should occur. Neven and Siotis (1996) present a similar argument, based on MNEs being attracted to particular locations by the prospects for 'technology sourcing’. Again in such cases, productivity spillovers from MNE to host-country firms are unlikely.

It is not the purpose of this paper to discuss at length the theoretical explanations of FDI, nevertheless, it is necessary, within the context of the above discussion, to consider other explanations of FDI. For example, Horstman and Markusen (1996), or Motta (1996), following Graham (1978), suggest that FDI can be explained as rivalrous behaviour between oligopolists, as well as in terms of ownership advantages or location advantages. Productivity externalities in the domestic sector may occur as a result of inward investment that is 
motivated by purely rivalrous behaviour. This may be either as a result of competitive pressures leading to increased productivity, or in the longer term, labour moving between competing firms for example. For the purpose of this paper, it is sufficient merely to note these competing (although possibly not mutually exclusive) explanations of FDI, and the resulting inferences concerning the likely impact on domestic productivity following the investment. However, it should also be noted, that there is compelling evidence, that whatever the motives for inward investment into the UK, the foreign owned sector possesses a significant productivity advantage over the domestic sector, see for example Davies and Lyons (1991), or Driffield (1996).

Given the existence of this productivity differential, there is another rationale for hypothesising that inward investment may generate host country productivity growth. This is based on the smaller literature, concerning the 'catching up' that occurs as a result of FDI. The process of 'catching up' occuring as a result of inward investment, is discussed at length in Perez (1998). Essentially, this is a more specific version of the hypothesis put forward by Caves and Barton (1990) and Perelman (1995), that future productivity growth is inversely related to current productivity levels. This is well established concept in more macroeconomic studies of factor productivity growth, Targetti and Foti (1997) provide a review of this literature.

The final factor which may cause inward investment to stimulate domestic productivity growth is simply that efficiency improvements are generated through increased competition. This possibility encompasses the explanations for FDI discussed above, including location advantage, or simply rivalry, rather than ownership advantages. Following foreign entry, increased competition is likely to increase exit rates at the industry level, which again would be expected to increase average industry productivity. 
It is not sufficient therefore merely to use 'inward investment' as a determinant of domestic productivity growth, but to focus on the nature of the investment. Important factors are; the size of the foreign advantage, the extent to which the inward investor carries out $R \& D$, the ability of the domestic sector to assimilate such information, and the scope for productivity gains in the industry. Pearce (1994) demonstrates that MNEs do carry out R\&D in host countries, but clearly this is not always the case. $R \& D$ is likely to accompany high value-added production, while low level assembly operations are unlikely to attract any $R \& D$ from the parent company.

\section{Measurement of productivity growth}

The discussion now turns to a model of productivity growth. Following Griliches (1992), the standard model of productivity growth describes the process in terms of a production function:

$\mathrm{Q}=\mathrm{AK} \mathrm{K}^{\alpha} \mathrm{R}^{\gamma}$

where:

$\mathrm{Q}=$ output

$\mathrm{K}=$ flow of capital services, proxied by the capital stock

$\mathrm{L}=$ flow of labour services, proxied by the number FTE employees

$\mathrm{R}=$ stock of research and development capital

The literature on productivity growth is strongly linked to that concerning spillovers. In the literature on spillovers, Griliches and Lichtenberg (1984), Haddad and Harrison (1993), Verspagen (1996) and Coe and Helpman (1995) for example, adopt the procedure of measuring productivity growth using total factor productivity growth. This methodology is summarised in Griliches (1995).

Output growth is represented in the following form:

$$
d \ln \mathrm{Q}_{\mathrm{i}}=d \mathrm{~A}_{\mathrm{i}} / \mathrm{A}_{\mathrm{i}}+\alpha^{*} d \ln \mathrm{K}_{\mathrm{i}}+\beta^{*} d \ln \mathrm{L}_{\mathrm{i}}+\gamma^{*} d \ln \mathrm{R}+\varepsilon_{\mathrm{i}}
$$


where $\alpha, \beta$ and $\gamma$ are marginal products of respective inputs, set equal to the shares of the factors in value added, and productivity growth is subsumed into the constant in equation (2). There is a relatively large literature, following Caballero and Lyons (1989, 1990, 1992), which essentially seeks to encompass the spillovers in terms of external output expansions. Oulton (1996) finds some evidence of this, although the results are very sensitive to the level of aggregation. Oulton (1997) discusses at length the potential problems with this approach, although many of these are essentially accounting problems at the macro level. Oulton (1997) nevertheless concludes that there is some evidence of externalities in productivity growth. The papers by Oulton (1997) and others, following Caballero and Lyons (1990) however, are concerned with a more general form of externality than that considered here. The focus here is a more specific question, the existence of spillovers from inward investment, rather than whether output spillovers exist per se. As such therefore, one of the major problems discussed in Oulton (1996), that of the error term from equation (2) being related to aggregate output growth (the externality in Oulton, 1996 and Caballero and Lyons, 1990) does not present its self. The sources of potential output and investment spillovers here are tightly defined, so it is unlikely that the 'spillover' variable will be related to the error term². This however is replaced by a similar problem, as to how one conceptualises externalities from inward investment. Previous work has simply attempted to specify productivity growth in terms of the externality, modelled in the $\mathrm{dA}_{\mathrm{i}} / \mathrm{A}_{\mathrm{i}}$ term. For example, Haddad and Harrison (1993) specify the externalities associated with inward investment in the following terms :

$$
\mathrm{dA}_{\mathrm{i}} / \mathrm{A}_{\mathrm{i}}=\mathrm{f}\left(\mathrm{INWARD}_{\mathrm{i}}\right)
$$

where INWARD is inward investment penetration.

One of the aims of this paper is to find an appropriate measure of inward investment, from which the spillover effect can be determined. Following Caballero and Lyons (1990) for 
example, it may be sufficient to include merely the output of the foreign owned sector, as a test for the externalities. However, given the results reported by Oulton (1996) and Basu and Fernald (1995), a more precise measure may be required. The appropriate measure of FDI that is to be used, must encapsulate the possibility of output spillovers and investment spillovers, as well as spillovers that occur through the act of FDI transferring superior knowledge capital to the UK.

\section{A model of productivity growth}

\subsection{Measuring inward investment}

Given that there are several reasons for expecting inward investment to boost domestic productivity, a suitable measure of inward investment must be found. Foreign penetration may be measured as the increase in foreign sales, employment or net capital investment, for example. Of these, sales (or value added) have the most intuitive appeal, in the spirit of the most general formulation of Caballero and Lyons (1990). However, given many of the arguments expressed in section 2, the actual investment (net capital expenditure) may be more appealing.

In addition, it is also important to allow for the relative size of the penetration, rather than merely the absolute level, which will vary with absolute industry size. This highlights one of the problems with previous literature in this area, where absolute levels of investment or sales are often employed as measures of inward investment, one suspects due to the lack of more appropriate data.

In order to allow for the possibility of both output spillovers and investment spillovers, the change in the log of foreign sales $\left(\mathrm{SALES} \mathrm{S}_{\mathrm{F}}\right.$ ), and the change in the log of foreign capital stock $\left(\mathrm{K}_{\mathrm{F}}\right)$ are used as measures of inward investment. These two measures will encompass any demonstration effect which is present, as this essentially involves the 
transfer of non-technological ownership advantages. In addition, foreign owned R\&D undertaken in the UK is also included, testing for R\&D spillovers, and the transfer of technology boosting domestic productivity growth. These measures however, are less likely to encompass the 'catching up' effect, which if present is likely to be a function of the productivity advantage possessed by the foreign sector. This is an extension of the 'catch up effect' employed by Caves and Barton (1990), and Perelman (1995). To encompass the possibility of catch up, lagged productivity in the foreign sector $\left(\mathrm{Q}_{\mathrm{F}} \mathrm{L}_{\mathrm{F}}\right)$ is included, following Davies and Lyons (1991). Spillovers, as defined by Griliches (1979, 1992) are illustrated through a relationship between productivity growth and external output, investment or R\&D. However, even in the absence of such spillovers, externalities are still possible, as firms respond to high-productivity entrants.

In addition to capital stock, R\&D and inward investment, there are other factors likely to influence productivity growth. For example, the skills mix of the labour force may change, with the firm choosing to employ different types of labour. Labour is therefore divided into manual labour (ML), and non-manual employees (NL).

Precise definitions and data sources for all variables are provided in appendix 1.

In dynamic terms, the following equation is derived from equations (1-3).

$$
\begin{aligned}
& \Delta \log \left(\mathrm{Q}_{\mathrm{i}}=\mathrm{b}_{0}+\mathrm{b}_{1} \Delta \log (\mathrm{K})_{\mathrm{i}}+\mathrm{b}_{2} \Delta \log (\mathrm{R})_{\mathrm{i}}+\mathrm{b}_{3} \Delta \log (\mathrm{ML})_{\mathrm{i}}+\mathrm{b}_{4} \Delta \log (\mathrm{NL})_{\mathrm{i}}+\right. \\
& \mathrm{b}_{5} \Delta \ln \left(\mathrm{R}_{\mathrm{F}}\right)_{\mathrm{i}} \mathrm{b}_{6} \Delta \ln (\operatorname{INWARD})_{\mathrm{i}}+\mathrm{b}_{7} \Delta \ln \left(\mathrm{Q}_{\mathrm{F}} \mathrm{L}_{\mathrm{F}}\right)_{\mathrm{t}-1 \mathrm{i}}
\end{aligned}
$$

Much of the work seeking to analyse spillovers from R\&D suffers from the combined problems of multicollinearity, and endogeneity. Many of the R\&D variables used in such studies are collinear, and there are many reasons to suppose that $R \& D$ is endogenous in the process of spillovers and productivity growth. Griliches (1979) for example points out, that 
not only will R\&D elsewhere affect the consequences of R\&D by the firm, but may also influence the desire of the firm to carry out R\&D. Indeed, Stadler (1992) suggests that R\&D expenditure may be lower overall in the presence of spillovers. Clearly, spillovers can occur in the opposite direction from that suggested thus far, with the foreign firms gaining from domestic R\&D, see for example Neven and Siotis (1996).

\subsection{The relationship between $R \& D$ and spillovers}

A common approach in the spillovers literature however, is to include a term for 'R\&D elsewhere' that may be expected to generate a positive externality, although it may also act to ‘crowd out' domestic R\&D or reduce potential returns to 'own' R\&D. This takes various forms, depending on whether the aim is to evaluate intra-industry spillovers (Bernstein, 1988), or inter-industry spillovers (Bernstein, 1989, Bernstein and Nadiri, 1988). The spillovers literature shows therefore that technology (as opposed to output) spillovers, can manifest themselves in one of two ways. Firstly R\&D may generate a positive externality, and secondly, the presence of external R\&D can serve to stimulate 'own' $R \& D$, in order to maximise the gain from the positive externality. In either case, it is likely that $\mathrm{R}$ will be endogenous in equation (4). This is a factor which is generally ignored in studies of technology externalities, but which may be crucial to the eventual econometric specification of equation (4). The alternatives therefore for modelling this, are to find an appropriate instrument for R, or to estimate equation (4) treating $\mathrm{R}$ as endogenous. This paper therefore turns briefly to focus on the likely determinants of R\&D expenditure.

\section{Determinants of R\&D expenditure}

The determinants of the attractiveness of $R \& D$ expenditure can be divided into three categories, from which a formal model may be devised. There are several works that present 
these arguments in depth, see for example Cohen (1995), Patel and Pavitt (1995) and Cohen and Levin (1989).

\subsection{Appropriabilty}

$\mathrm{R} \& \mathrm{D}$ expenditure, is at least in part determined by the ability of the firm to assimilate the output of such expenditure. $\mathrm{R} \& \mathrm{D}$ is therefore seen as being dependent on the technological competence of the firm, proxied using indicators such as the capital/labour ratio. This highlights the inherent endogeneity problem in seeking to determine the impact of R\&D. For example, as Levin (1988) notes, the possibility of spillovers are at once likely to discourage and encourage $R \& D$. $R \& D$ elsewhere is likely to influence levels of 'own' $R \& D$, either through the desire to be technologically competitive, or through the desire to maximise the acquired spillover. However, it may also discourage investment in $R \& D$, due to the increased likelihood of competitors being able to appropriate any technological improvement. Foreign-owned R\&D in the UK therefore may have the effect of discouraging domestic R\&D, through the likelihood of any technological advance being quickly appropriated by the foreign sector. Finally, there is the possibility that there is competition for R\&D capital, and domestic R\&D is 'crowded out' by foreign R\&D expenditure.

\subsection{Market Conditions}

Investigation of the relationship between the market conditions and research intensity dates back to Kamien and Schwartz (1970). Cohen and Levin (1989) suggest that R\&D expenditure will be greater, the lower the elasticity of demand. The standard way of approaching this problem has been to attempt to relate market structure to research intensity. However, as many researchers report, it is often impossible to reject the hypothesis of concentration being endogenous in models of R\&D (Connely and Hirschey, 1984, Levin et $a l, 1985)$. In addition to these conditions, it also necessary to consider market size, and rate of 
growth of market size, (Jaffe, 1988). These are in turn related to the final set of determinants of R\&D, based on the firms’ ability to finance the investment.

\subsection{Availability of Funds}

It is one of the essential premises of technological advance that $R \& D$ should be related to past firm performance, based on the need of the firm to generate funds in order to finance R\&D. Himmelberg and Petersen (1994) for example demonstrate that there is a significant relationship between R\&D and the availability of internal finance, based on cash flow. Past profits are used as an indicator of the availability of funds, in conjunction with sales, and the growth of sales.

\subsection{A model of $R \& D$ expenditure}

Industry SALES, and GROWTH of sales over the three years up to the start of the period, are used to proxy demand conditions. In finding a suitable proxy for market conditions, concentration has an obvious appeal, but it is likely to be endogenous. Therefore, advertising intensity (ADV) at the start of the period is included, as a proxy for the elasticity of demand. The technological capability to benefit from the output of R\&D is proxied using the capital-labour ratio at the industry level. Finally, past profits are included as a measure of the availability of funds for R\&D.

$R \& D$ elsewhere is divided into foreign-owned $R \& D\left(R_{F}\right)$ and domestic $R \& D$ elsewhere within the sector (R2). The extent to which foreign-owned $R \& D$ stimulates domestic $R \& D$, then tests the extent to which inward investment stimulates technological advance through increased $R \& D$ expenditure.

The R\&D equation is specified as follows :

$\Delta \log (\mathrm{R})_{\mathrm{i}}=\alpha_{0}+\alpha_{1} \log (\mathrm{K} / \mathrm{L})_{\mathrm{i}}+\alpha_{2} \log (\mathrm{ADV})_{\mathrm{i}}+\alpha_{3} \log (\mathrm{GROWTH})_{\mathrm{i}}+$ 
$\alpha_{4} \log (\mathrm{PROFIT})_{\mathrm{i}}+\alpha_{5} \Delta \log \left(\mathrm{R}_{\mathrm{F}}\right)_{\mathrm{i}}+\alpha_{6} \Delta \log (\mathrm{R} 2)_{\mathrm{i}}+\mathrm{U}_{2 \mathrm{i}}$

This is a similar specification to that employed in this area previously, see for example Switzer (1984), Culbertson (1985), and Cohen and Levinthal (1989). Expression (5) however, in addition to testing the theoretical determinants of $\mathrm{R} \& \mathrm{D}$ outlined above, also tests the extent to which foreign owned and domestic R\&D in the UK may be seen as complementary, or whether one merely 'crowds out' the other.

Equations (4) and (5) are estimated using Full Information Maximum likelihood, treating $\Delta \log (\mathrm{R})$, and $\Delta \log (\mathrm{Q})$ as endogenous. ${ }^{4}$

\section{The data}

Precise definitions of the variables used are given in appendix 1 . The data used are at the SIC (1980) 3 digit level, taken from various Business Monitor publications. These provide data on employment, divided into manual and non manual workers, investment, value added, and profitability. In addition, data on $R \& D$ and advertising expenditure were obtained. and The UK ONS provided corresponding data for the foreign owned sector only, therefore data for the domestic sector could be calculated. After omitting various ‘miscellaneous’ categories, this provided 103 observations, for the years 1989 and 1992.

\section{Results}

The results for the estimation of equations (4) and (5) are given in Table 1 below.

table 1 here

These results demonstrate that domestic $R \& D$ expenditure does generate productivity growth. The results also illustrate why there is much contradiction in the literature concerning the measurement of $R \& D$ spillovers in the literature. It is clear that $R \& D$ must be seen as 
endogenous in the process of productivity growth, and as such, any attempt to estimate R\&D spillovers within a single equation framework may generate spurious results. In addition, the results also show that it is important to make the distinction between the two types of labour, as this greatly improves the specification of the model. The tests of functional form confirm that a Cobb-Douglas specification is appropriate for these data.

There is no evidence of 'pure' R\&D spillovers from foreign owned R\&D in the UK. Equally, there is no evidence of investment or output spillovers from inward investment ${ }^{5}$. However, these results show that past foreign productivity growth, does lead to productivity growth in the domestic sector ${ }^{6}$. The results suggest that the domestic sector is able to assimilate some $15 \%$ of any productivity growth generated by the foreign sector, but with a lag such that the foreign productivity differential is likely to be maintained. As such, the results suggest that the foreign productivity advantage was responsible for an average increase in domestic productivity of $0.75 \%$ a year.

Turning to the results from the $R \& D$ equation in table 2 , the most important result in terms of the impact of FDI, is that foreign R\&D appears to 'crowd out' domestic R\&D at the rate of approximately $10 \%$. This however is equivalent to only $0.3 \%$ of domestic $R \& D$, and so has a negligible effect on domestic productivity

\section{Table 2 here}

The other variables in the equation have the expected effects. Capital intensity is an important determinant of $R \& D$ expenditure, suggesting that $R \& D$ is stimulated by the ability of the firm to assimilate new technology in the production process. In addition, R\&D is positively related to advertising intensity, suggesting that inelastic demand in the product market stimulates R\&D. In addition, these results confirm the hypothesis of Himmelberg and 
Petersen (1994), that the availability of funds is an important determinant of $R \& D$ expenditure. Interestingly however, there is no evidence that domestic R\&D in related industries influences industry level $R \& D$, in the manner that the foreign sector does. One possible explanation for these results, is that firms carry out less $R \& D$, in the presence of (possibly superior) foreign $\mathrm{R} \& \mathrm{D}$, or as a result of the knowledge gained by interacting with high productivity inward investorts.

\section{Conclusions.}

This paper demonstrates that there is no evidence of output, R\&D or investment spillovers occurring as a result of inward investment. However, one significant result is that 'catching up' does occur, in industries where the foreign owned sector has a demonstrable productivity advantage over the domestic sector. This suggests that domestic firms, faced with a more efficient competitor, seek to improve efficiency. This therefore suggests that the most likely benefit to the UK, in terms of attracting inward investment, is the increased competition, which then stimulates domestic productivity growth. This concurs with the result reported in Driffield and Munday (1998), that large scale inward investment generates a reduction in domestic industry profitability. This broadly concurs with the result reported by Barrel and Pain (1997), who estimate that a 1\% increase in the stock inward investment in UK manufacturing boosts technical progress in the sector by $0.26 \%$. This effect is strongest where the UK firms are relatively less productive. They do not however distinguish between spillovers, catching up, or the effect of new inward investment simply increasing average productivity. These alternative scenarios are of course not mutually exclusive, the outcome probably being a combination of all three.

This paper goes some way to evaluating the productivity gains that the UK may experience as a result of foreign entry, as well as explaining many of the seemingly 
contradictory results in previous work. A desirable extension to this paper would be a panel type study, to test the stability of these results over different time periods. This however awaits more data for R\&D in the foreign sectors of UK manufacturing.

\section{Appendix 1 : The data}

The data that are used here are in the most part taken from various years of The Report on The Census of Production. These are industry level data, taken at the three digit level for manufacturing, SIC(1980) categories 2-4. Data on the foreign owned sector only at the 3 digit level, were provided by the ONS, such that domestic industry data can be derived. The exceptions to this are the advertising data, which are for the total industry.

\section{Definitions of the variables:}

All the data are annual, and the data used are the differences between 1989 and 1992. All monetary variables are expressed in real terms (1989 prices).

Q is value added, as defined in the Report on the Census of Production.

$\mathrm{K}$ is the capital stock of the domestic industry, the change in this is given by net capital investment, in the UK owned sector. This is expressed in $£$ millions. Data on the capital stock are not available at this level of aggregation, so the sum of net investment over the previous ten years is used as a proxy. A standard depreciation rate of $10 \%$ is used.

$\mathrm{R}$ is $\mathrm{R} \& \mathrm{D}$ expenditure, carried out by the domestic industry. The stock of $\mathrm{R} \& \mathrm{D}$ is measured as the sum of R\&D expenditure from 1981 to 1989 , depreciated at the standard rate of $10 \%$ p.a. This is available in Business Monitors MO14.

ML is employment of operatives in domestic owned industry.

NL is employment of non-operatives in domestic owned industry. 
$\mathrm{Q}_{\mathrm{F}} \mathrm{L}_{\mathrm{F}}$ is the measure of labour productivity in the foreign sector, value added per employee. The change in this is specified over the time period prior to the period in question, 1986-1989.

$\mathrm{R}_{\mathrm{F}}$ is the stock of foreign-owned R\&D expenditure in the industry. Historical data on foreign-owned R\&D expenditure are not available before 1986, so the stock of foreign $R \& D$ is estimated on this basis, depreciating the stock at $10 \%$ p.a.

SALES $_{\mathrm{F}}$ : sales by foreign owned firms operating in the UK

$\mathrm{R} 2$ is domestic R\&D in other industries within the same 2 digit sector.

ADV : Industry advertising intensity. Advertising expenditure data are taken from The Advertising Statistics Yearbook for 1989. This is then divided by total industry sales. 


\section{References}

Barrell, R. \& Pain, N. (1997) "Foreign direct investment, technological change, and economic growth within Europe.” Economic Journal, Vol. 107, No. 445, pp. 1770-1786.

Basu, S. and Fernald, J.G. (1995) "Are apparent productive spillover effects a figment of specification error ?” Journal of Monetary Economics, Vol. 36, No.1, pp. 165-188.

Bernstein, J.I. (1988) "Costs of production, intra- and interindustry R\&D spillovers: Canadian evidence.” Canadian Journal of Economics, Vol. 21, No. 2, pp. 325-347.

Bernstein, J.I. (1989) "The structure of Canadian interindustry R\&D spillovers, and the rates of return to R\&D.” Journal of Industrial Economics, Vol. 37, No. 3, pp. 315-328.

Bernstein, J.I. Nadiri, I. (1988) "Interindustry R\&D spillovers, rates of return, and production in high - tech industries.” American Economic Review, Vol. 78, No. 2, pp. 429-434.

Blomstrom, M (1986) "Foreign Investment and productive Efficiency: The case of Mexico." Journal of Industrial Economics, Vol. 35, No. 1, pp. 97-110

Blomstrom, M. and Kokko, A. (1996) "Multinational corporations and spillovers.” CEPR discussion paper no 1365.

Blomstrom, M. and Persson, H. (1983) "Foreign investment and "spillover" efficiency in an underdeveloped economy. Evidence from Mexican manufacturing industry." World Development, Vol. 11, No. 6, pp. 493-501.

Brainard, S. L. (1997) "An Empirical Assessment of the Proximity-Concentration Trade-off between Multinational Sales and Trade.” American Economic Review, Vol. 87, No. 4, pp. 520-44.

Caballero, R.J. and Lyons, R.K. (1989) "The role of external economies in US manufacturing.” NBER working paper no. 3033.

Caballero, R.J. and Lyons, R.K. (1990) "Internal versus external economies in European industry.” European Economic Review, Vol. 34, No. 4, pp. 805-30.

Caballero, R.J. and Lyons, R.K. (1992) "External effects in US procyclical productivity." Journal of Monetary Economics, Vol. 29, No. 2, pp. 209-225.

Cantwell, J.A. (1989) Technological innovation and multinational corporations. Basil Blackwell, Oxford.

Caves, R.E. and Barton, D.R. (1990) Efficiency in U.S. manufacturing industries. MIT Press, Cambridge, Massachusetts.

Coe, D.T. and Helpman, E. (1995) “International R\&D Spillovers.” European Economic Review, Vol. 39, No. 5, pp. 859-87.

Cohen, W.M. (1995) “Empirical studies of innovative activity.” In Stoneman, P. (ed.) Handbook of the economics of innovation and technological change. Blackwell, Oxford. 
Cohen, W.M. and Levin, R.C. (1989) "Empirical studies of innovation and market structure." In R. Schmalensee and R.D. Willig (eds.) Handbook of Industrial Organization, Elsvier Science Publishers.

Cohen, W.M. and Levinthal, D.A. (1989) “Innovation and learning: The two faces of R\&D.” Economic Journal, Vol. 99, No. 397, pp. 569-596.

Connolly, R.A. and Hirschey, M. (1984) "R\&D, market structure and profits, a value based approach.” The Review of Economics and Statistics, Vol. 66, No. 4, pp. 682-686.

Culbertson, J.D. (1985) "Econometric tests of the market structural determinants of R\&D investment : Consistency of absolute and relative firm size models. The Journal of Industrial Economics, Vol. 34, No. 1, pp. 101-108.

Davies, S.W. and Lyons, B.R. (1991) "Characterising relative performance: The productivity advantage of foreign owned firms in the UK.” Oxford Economic Papers, Vol. 43, No. 4, pp. 584-595.

Department of Trade and Industry, (1991) A study into the knock-on effects of inward investment in the English Regions, HMSO, London.

Driffield, N.L. (1996) Global competition and the labour market. Harwood, Reading.

Driffield, N.L. and Munday, M.C. (1998) “The Impact of Foreign Direct Investment on UK Manufacturing: Is there a profit squeeze in domestic firms?” Applied Economics, Vol. 30, No. 5 pp. 705-709.

Dunning, J.H. (1979) "Explaining patterns of international production: In defence of the eclectic theory.” Oxford Bulletin of Economics and Statistics, Vol. 41, No. 4, pp. 269-95.

Eltis, W. (1996) "How low productivity and weak innovativeness undermines UK industrial growth.” Economic Journal, Vol. 106, No. 434, pp. 184-195.

Eltis, W. and Fraser, D. (1992) "The contribution of the Japanese industrial success to Britain and Europe, Nat West Bank Economic Review, Vol. 0, No. 0, pp. 2-19.

Graham, E.M. (1978) "Transatlantic investment by multinational firms: A rivalistic phenomenon ?” Journal of Post Keynesian Economics, Vol. 1, No. 1, pp. 82-99.

Griliches, Z. (1979) “Issues in assessing the contribution of R\&D to productivity growth". Bell Journal of Economics, Vol. 10, No. 1, pp. 92-116.

Griliches, Z. (1986) "Productivity, R\&D, and basic research at the firm level in the 1970s." American Economic Review, Vol. 76, No. 1, pp. 141-154.

Griliches, Z. (1992) “The search for R\&D spillovers”. Scandinavian Journal of Economics, Vol. 94, supplement, pp. 29-47.

Griliches, Z. (1995) "R\&D and productivity: Econometric results and measurement issues." In Stoneman, P. (ed.) Handbook of the economics of innovation and technological change. Basil Blackwell, Oxford. 
Griliches, Z. and Lichtenberg, F, (1984) "Interindustry technology flows and productivity growth: A reexamination.”. Review of Economics and Statistics, Vol. 66, No. 2, pp. 324-29.

Haddad, M. and Harrison, A. (1993), "Are there positive spillovers from foreign investment ? Evidence from panel data for Morocco.” Journal of Development Economics, Vol. 42, No. 1, pp. 51-74.

Hausman, J.A. (1978) "Specification tests in econometrics.” Econometrica, Vol. 46, No. 6, pp. 1251-1271.

Horstmann, I.J. and Markusen, J.R. (1996) "Exploring new markets: Direct investment, contractual relations and the multinational enterprise." International Economic Review, Vol. 37, No. 1, pp. 1-19.

Himmelberg, C.P. and Petersen, B.C. (1994) "R\&D and internal finance - a panel study of small firms in high-tech industries”. The Review of Economics and Statistics, Vol. 76, No. 1, pp. 38-51

Invest in Britain Bureau (1996) Annual Report, HMSO, London.

Invest in Britain Bureau (1997) Annual Report, HMSO, London.

Jaffe, A.B. (1988) "Demand and supply influences in R\&D intensity and productivity growth.” The Review of Economics and Statistics, Vol. 70, No. 3, pp. 431-437

Kamien, M.I. and Schwartz, N.L. (1970) "Market structure, elasticity of demand, and incentive to invent”. Journal of Law and Economics, Vol. 13, No. 1, pp. 241-252.

Levin, R.C. (1988) “Appropriability, R\&D spending and technological performance.” American Economic Review, Vol. 78, No. 2, pp. 424-428.

Markusen, J.R. (1995) "The boundaries of multinational enterprises and the theory of international trade.” Journal of Economic Perspectives, Vol. 9, No. 2, pp. 169-189.

Maskus, K.E. and Webster, A. (1995), "Competitive advantage and the location of inward foreign direct investment: Evidence from the UK and South Korea.” World Economy, Vol. 18, No. 2, pp. 315-328.

Motta, M (1996) Multinationals without advantages. Universitat Pompeu Fabra, mimeo.

Neven, D. and Siotis, G (1996) "Technology sourcing and FDI in the EC: An empirical evaluation”. International Journal of Industrial Organization, Vol. 14, No. 5, pp. 543-560.

Oulton, N (1996) "Increasing returns and externalities in UK manufacturing : Myth or reality ?” Journal of Industrial Economics, Vol. 44, No. 1, pp. 99-113.

Oulton, N (1997) “Total factor productivity growth and the role of externalities.” National Institute Economic Review, no. 162 pp. 99-111

Patel, P. and Pavitt, K. (1995) Patterns of technological activity: their measurement and interpretation. In Stoneman, P. (ed.) Handbook of the economics of innovation and technological change. Blackwell, Oxford. 
Pearce, R.D. (1993) The growth and evolution of the multinational enterprise. Edward Elgar, London.

Pearce, R.D. (1994) "The determinants of the geographical diversification of R\&D by MNEs.” In Cantwell, J.A. (ed.) Transnational corporations and innovatory activities. UN library on transnational corporations, Vol. 17. Routledge, London.

Perelman, S. (1995) "R\&D, technological progress and efficiency change in industrial activities.” Review of Income and Wealth, Vol. 41, No. 3, pp. 349-366.

Perez, T. (1998) Multinational enterprises and technological spillovers. Harwood, Reading.

Stadler, M (1992) "Determinants of innovative activity in oligopolistic markets." Journal of Economics, Vol. 56, No. 2, pp. 137-156.

Switzer, L. (1984) "The determinants of industrial R\&D : A funds flow simultaneous equation approach.” The Review of Economics and Statistics, Vol. 66, No. 1, pp. 163-168.

Targetti, F. and Foti, A. (1997) "Growth and productivity: A model of cumulative growth and catching up.” Cambridge Journal of Economics, Vol. 21, No. 1, pp. 27-43.

Wang, J-Y. and Blomstrom, M. (1992) "Foreign investment and technology transfer. A simple model.” European Economic Review, Vol. 36, No. 1, pp. 137-55.

Welsh Affairs Committee (1988) Inward investment into Wales and its interaction with regional and EEC policies, HMSO, London. 
Table 1

\section{Productivity Growth Equations}

\begin{tabular}{|c|c|c|}
\hline Dependent variable & $\Delta \log \mathbf{Q}$ & $\Delta \log Q$ \\
\hline Constant & $\begin{array}{c}0.0962^{* *} \\
(7.87)\end{array}$ & $\begin{array}{c}0.095^{* *} \\
(7.67) \\
\end{array}$ \\
\hline$\Delta \log (\mathrm{K})$ & $\begin{array}{l}0.299 * * \\
(3.101)\end{array}$ & $\begin{array}{l}0.294 * * \\
(3.481) \\
\end{array}$ \\
\hline$\Delta \log (\mathrm{R})$ & $\begin{array}{c}0.077^{* *} \\
(3.10) \\
\end{array}$ & $\begin{array}{c}0.084^{* *} \\
(3.53)\end{array}$ \\
\hline$\Delta \log (\mathrm{ML})$ & $\begin{array}{c}0.343^{* *} \\
(4.81)\end{array}$ & $\begin{array}{c}0.321^{* *} \\
(4.98)\end{array}$ \\
\hline$\Delta \log (\mathrm{NL})$ & $\begin{array}{c}0.279 * * \\
(2.91)\end{array}$ & $\begin{array}{c}0.300^{* *} \\
(2.11)\end{array}$ \\
\hline$\Delta \log \left(\mathrm{Q}_{\mathrm{F}} / \mathrm{L}_{\mathrm{F}}\right)_{86-89}$ & $\begin{array}{c}0.152^{* *} \\
(4.43) \\
\end{array}$ & $\begin{array}{c}0.148^{* *} \\
(4.40) \\
\end{array}$ \\
\hline$\Delta \log (\mathrm{RF})$ & $\begin{array}{l}0.006 \\
(0.60)\end{array}$ & $\begin{array}{c}0.0014 \\
(0.42)\end{array}$ \\
\hline$\Delta \log \left(\mathrm{K}_{\mathrm{F}}\right)$ & $\begin{array}{l}0.055 \\
(1.38) \\
\end{array}$ & \\
\hline$\Delta \log \left(\mathrm{SALES} \mathrm{S}_{\mathrm{F}}\right)$ & & $\begin{array}{l}0.035 \\
(1.33) \\
\end{array}$ \\
\hline Mean of dep. Var. & 0.137 & \\
\hline SSR & 2.45 & 2.63 \\
\hline $\mathrm{R}^{2}$ & 0.639 & 0.645 \\
\hline Observations & 103 & 103 \\
\hline $\begin{array}{l}\text { Heteroscedasticity } \\
\chi^{2}(1)^{7}\end{array}$ & $\begin{array}{c}0.57 \\
(0.45) \\
\end{array}$ & $\begin{array}{c}0.56 \\
(0.53) \\
\end{array}$ \\
\hline $\begin{array}{l}\text { Functional form } \\
\chi^{2}(1)^{8}\end{array}$ & $\begin{array}{c}0.37 \\
(0.54)^{+}\end{array}$ & $\begin{array}{c}0.36 \\
(0.55)^{+}\end{array}$ \\
\hline \multicolumn{3}{|l|}{$\mathrm{F}$} \\
\hline $\log \mathrm{L}$ & 46.75 & 46.50 \\
\hline
\end{tabular}

${ }^{+} \mathrm{p}$ values 
Table 2

\section{R\&D Equation ${ }^{9}$}

\begin{tabular}{|l|l|}
\hline & Coefficient \\
\hline Constant & $1.570^{* *}$ \\
& $(3.28)$ \\
\hline Log (K/L) & $0.0211^{* *}$ \\
& $(2.05)$ \\
\hline Log (ADV) & $0.0176^{* *}$ \\
& $(2.72)$ \\
\hline Log (GROWTH) & $0.6410^{* *}$ \\
& $(2.14)$ \\
\hline Log (PROFIT) & $0.2296^{* *}$ \\
& $(3.43)$ \\
\hline$\Delta \log (\mathrm{RF})$ & $-0.1012^{* *}$ \\
& $(2.50)$ \\
\hline$\Delta \log (\mathrm{R} 2)$ & 0.1214 \\
& $(0.224)$ \\
\hline & \\
\hline Mean of dependent variable & 0.934 \\
\hline Sum of squared residuals & 37.64 \\
\hline Std. Error of regression & \\
\hline $\mathrm{R}^{2}$ & 0.504 \\
\hline Heteroscedasticity $\chi^{2}(1)$ & 0.56 \\
(p value) & $(0.50)$ \\
\hline Functional form $\chi^{2}(1)$ & 0.62 \\
(p value) & $(0.43)$ \\
\hline
\end{tabular}

**significant at the $1 \%$ level. 
Appendix 2: The Impact of Other Measures of Inward Investment

\begin{tabular}{|c|c|c|c|c|c|c|}
\hline Dependent variable & $\Delta \log Q$ & $\Delta \log \mathbf{Q}$ & $\Delta \log Q$ & $\Delta \log \mathbf{Q}$ & $\Delta \log Q$ & $\Delta \log \mathbf{Q}$ \\
\hline Constant & $\begin{array}{l}0.081 \\
(0.86)\end{array}$ & $\begin{array}{l}0.073 \\
(0.71)\end{array}$ & $\begin{array}{l}0.093 \\
(0.84)\end{array}$ & $\begin{array}{l}0.076 \\
(0.81)\end{array}$ & $\begin{array}{l}0.076 \\
(0.81)\end{array}$ & $\begin{array}{l}0.092 \\
(0.94\end{array}$ \\
\hline$\Delta \log (\mathrm{K})$ & $\begin{array}{l}0.297 \\
(4.62)\end{array}$ & $\begin{array}{l}0.297 \\
(4.04)\end{array}$ & $\begin{array}{l}0.296 \\
(4.75) \\
\end{array}$ & $\begin{array}{l}0.298 \\
(4.63) \\
\end{array}$ & $\begin{array}{l}0.298 \\
(4.59) \\
\end{array}$ & $\begin{array}{l}0.306 \\
(4.74 \\
\end{array}$ \\
\hline$\Delta \log (\mathrm{R})$ & $\begin{array}{l}0.053 \\
(2.80)\end{array}$ & $\begin{array}{l}0.051 \\
(2.79)\end{array}$ & $\begin{array}{l}0.055 \\
(2.91)\end{array}$ & $\begin{array}{l}0.047 \\
(2.93)\end{array}$ & $\begin{array}{l}0.047 \\
(2.73)\end{array}$ & $\begin{array}{l}0.051 \\
(2.94)\end{array}$ \\
\hline$\Delta \log (\mathrm{ML})$ & $\begin{array}{l}0.336 \\
(7.51)\end{array}$ & $\begin{array}{l}0.337 \\
(7.43)\end{array}$ & $\begin{array}{l}0.338 \\
(77.9)\end{array}$ & $\begin{array}{l}0.338 \\
(7.69)\end{array}$ & $\begin{array}{l}0.339 \\
(7.41)\end{array}$ & $\begin{array}{l}0.325 \\
(7.41)\end{array}$ \\
\hline$\Delta \log (\mathrm{NL})$ & $\begin{array}{l}0.313 \\
(5.10)\end{array}$ & $\begin{array}{l}0.315 \\
(4.92) \\
\end{array}$ & $\begin{array}{l}0.310 \\
(4.87) \\
\end{array}$ & $\begin{array}{c}0.318 \\
(5.011) \\
\end{array}$ & $\begin{array}{l}0.316 \\
(3.99)\end{array}$ & $\begin{array}{l}0.318 \\
(3.99)\end{array}$ \\
\hline$\Delta \log \left(\mathrm{Q}_{\mathrm{F}} / \mathrm{L}_{\mathrm{F}}\right)_{86-89}$ & $\begin{array}{l}0.142 \\
(4.01)\end{array}$ & $\begin{array}{l}0.157 \\
(4.04)\end{array}$ & $\begin{array}{l}0.121 \\
(3.79)\end{array}$ & $\begin{array}{l}0.162 \\
(3.89) \\
\end{array}$ & $\begin{array}{l}0.164 \\
(3.99)\end{array}$ & $\begin{array}{l}0.127 \\
(3.89)\end{array}$ \\
\hline$\Delta \log \left(R_{F}\right)$ & $\begin{array}{l}0.0051 \\
(0.64) \\
\end{array}$ & $\begin{array}{l}0.0062 \\
(0.53)\end{array}$ & $\begin{array}{c}0.0055 \\
(0.57)\end{array}$ & $\begin{array}{c}0.0058 \\
(0.64)\end{array}$ & $\begin{array}{l}0.0061 \\
(0.67)\end{array}$ & $\begin{array}{l}0.0061 \\
(0.67)\end{array}$ \\
\hline$\Delta \log \left(\mathrm{Q}_{\mathrm{F}} / \mathrm{L}_{\mathrm{F}}\right)_{89-92}$ & & & & & & $\begin{array}{c}0.064^{10} \\
(0.95) \\
\end{array}$ \\
\hline $\log \left(\mathrm{K}_{\mathrm{F}} / \mathrm{K}_{\mathrm{D}}\right)$ & $\begin{array}{c}0.0006 \\
(0.19)\end{array}$ & & & & & \\
\hline $\log \left(\mathrm{SALES}_{\mathrm{F}} / \mathrm{SALES}_{\mathrm{D}}\right)$ & & $\begin{array}{l}0.0002 \\
(0.06) \\
\end{array}$ & & & & \\
\hline $\log \left(K_{F}\right)$ & & & $\begin{array}{c}-0.0004 \\
(1.04) \\
\end{array}$ & & & \\
\hline$\Delta \log \left(\mathrm{SALES} \mathrm{S}_{\mathrm{F}}\right)_{\mathrm{t}-1}$ & & & & $\begin{array}{r}0.0020 \\
(0.140) \\
\end{array}$ & & \\
\hline$\Delta \log \left(\mathrm{K}_{\mathrm{F}}\right)_{\mathrm{t}-1}$ & & & & & $\begin{array}{c}0.06 \\
(0.12) \\
\end{array}$ & \\
\hline Mean of dep. Var. & 0.137 & 0.137 & 0.137 & 0.137 & 0.137 & 0.137 \\
\hline SSR & 2.21 & 2.30 & 2.14 & 2.31 & 2.30 & 2.36 \\
\hline $\mathrm{R}^{2}$ & 0.57 & 0.57 & 0.57 & 0.56 & 0.57 & 0.55 \\
\hline $\begin{array}{l}\text { Heteroscedasticity } \\
\chi^{2}(1)^{11}\end{array}$ & 0.47 & 0.49 & 0.48 & 0.51 & 0.78 & 0.52 \\
\hline $\begin{array}{l}\text { Functional form } \\
\chi^{2}(1)^{12} \text { : }\end{array}$ & 0.42 & 0.42 & 0.43 & 0.42 & 0.43 & 0.44 \\
\hline $\mathrm{F}$ & 58.92 & 58.64 & 57.72 & 58.62 & 57.91 & 57.65 \\
\hline $\log L$ & 46.24 & 46.31 & 47.10 & 46.61 & 46.81 & 46.70 \\
\hline
\end{tabular}




\footnotetext{
${ }^{1}$ For references to UK government policy, see Eltis (1996), Eltis \& Fraser (1992), IBB (1996, 1997), Welsh Affairs Committee (1988), DTI (1991).

${ }^{2}$ See Oulton (1996) for a full discussion of this. Empirically this can be tested for using standard heteroskedasticity tests.

${ }^{3}$ The INWARD term in equation (4) covers the alternative measures of inward investment, such as foreign SALES or INVESTMENT. Testing for output or investment spillovers in this framework must be carried out separately due to likely multicollinearity, but are included in turn. The results from the estimation of the different specifications of equation (4), are given in table 1.

${ }^{4} \mathrm{~A}$ basic endogeneity test, shows that own R\&D is indeed endogenous. Equally it is impossible to reject the hypothesis that either $\Delta \log \left(\mathrm{Q}_{\mathrm{F}} / \mathrm{L}_{\mathrm{F}}\right)$ or $\log (\mathrm{K} / \mathrm{L})$ are exogenous in their respective equations. A Hausman (1978) test confirms that the FIML approach used here is the appropriate one, rather than two or three stage least squares, where the instrument is lagged $R \& D$ expenditure.

${ }^{5}$ One way to test the relative importance of the two effects, is to estimate equation (4) without the foreign productivity variable, to determine whether the insignificance of the inward investment variable is due to the presence of $\mathrm{Q}_{\mathrm{F}} / \mathrm{L}_{\mathrm{F}}$. There is no evidence that this is the case.

${ }^{6}$ Given these results, other specifications of the inward investment variables were tried, such as the stock rather than flow of investment, the relative size of the foreign sector, and the level of sales. Also used were the lags of the variables, to test whether the time lag allowed for was insufficient. None of these variables are significant, and all are rejected using a standard LM variable addition test. The results from such models are presented in appendix two.

${ }^{7}$ Test based on regression of squared residuals on squared fitted values.

${ }^{8}$ Ramsey's RESET test based on the squares of the fitted values.

${ }^{9}$ The results presented here are for the estimation of equation (5), simultaneously with the specification of equation (4), using $\Delta \ln (\mathrm{Q})$ as the dependent variable, and $\Delta \ln \mathrm{K}_{\mathrm{F}}$ as the inward investment variable. However, the results for equation (5) are almost identical across all specifications of equation (4), and so for the sake of brevity, the others are omitted.

${ }^{10}$ There is no evidence that $\Delta \log \left(\mathrm{Q}_{\mathrm{F}} / \mathrm{L}_{\mathrm{F}}\right)_{89-92}$ and $\Delta \log \left(\mathrm{Q}_{\mathrm{F}} / \mathrm{L}_{\mathrm{F}}\right)_{86-89}$ are collinear.

${ }^{11}$ Test based on regression of squared residuals on squared fitted values.

${ }^{12}$ Ramsey's RESET test based on the squares of the fitted values.
} 